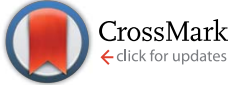

Cite this: Chem. Sci., 2015, 6, 6925

Received 18th July 2015

Accepted 10th August 2015

DOI: $10.1039 / c 5 s c 02607 e$

www.rsc.org/chemicalscience

\section{Control of cerium oxidation state through metal complex secondary structures $\dagger$}

\begin{abstract}
Jessica R. Levin, Walter L. Dorfner, Patrick J. Carroll and Eric J. Schelter*
A series of alkali metal cerium diphenylhydrazido complexes, $\mathrm{M}_{x}(\mathrm{py})_{y}\left[\mathrm{Ce}(\mathrm{PhNNPh})_{4}\right], \mathrm{M}=\mathrm{Li}, \mathrm{Na}$, and $\mathrm{K}, x=$ $4(\mathrm{Li}$ and $\mathrm{Na}$ ) or $5(\mathrm{~K})$, and $y=4(\mathrm{Li}), 8(\mathrm{Na})$, or $7(\mathrm{~K})$, were synthesized to probe how a secondary coordination sphere would modulate electronic structures at a cerium cation. The resulting electronic structures of the heterobimetallic cerium diphenylhydrazido complexes were found to be strongly dependent on the identity of the alkali metal cations. When $\mathrm{M}=\mathrm{Li}^{+}$or $\mathrm{Na}^{+}$, the cerium(II) starting material was oxidized with concomitant reduction of 1,2-diphenylhydrazine to aniline. Reduction of 1,2-diphenylhydrazine was not observed when $\mathrm{M}=\mathrm{K}^{+}$, and the complex remained in the cerium(III) oxidation state. Oxidation of the cerium(III) diphenylhydrazido complex to the Ce(Iv) diphenylhydrazido one was achieved through a simple cation exchange reaction of the alkali metals. UV-Vis spectroscopy, FTIR spectroscopy, electrochemistry, magnetic susceptibility, and DFT studies were used to probe the oxidation state and the electronic changes that occurred at the metal centre.
\end{abstract}

\section{Introduction}

Cerium is unique among the lanthanides because of its accessible +4 oxidation state $\left(E^{\circ}\left(\mathrm{Ce}^{\mathrm{IV} / \mathrm{III}}\right)=1.40 \mathrm{~V}\right.$ vs. $\left.\mathrm{Fc} / \mathrm{Fc}^{+}\right) \cdot \cdot^{1-3}$ Considering its standard reduction potential, Ce(Iv) complexes are best known as one-electron oxidants in inorganic and organic syntheses, as well as in materials chemistry. ${ }^{\mathbf{4 - 1 6}}$ For example, ceric ammonium nitrate (CAN), has been used in water oxidation, oxidation of alcohols, oxidative carbon-carbon coupling reactions, and in oxidative deprotection of ketones and acetals. ${ }^{4,10}$ In materials chemistry cerium has been used in both oxidative and reductive contexts. Cerium(Iv) dioxide (ceria) and related materials are applied in catalytic redox cycling devices, such as in fuel cells, ${ }^{15,17-21}$ active supports in 3-way catalytic converters, ${ }^{22-24}$ for the water gas shift reaction, ${ }^{25-28}$ and in heterogeneous catalysis for organic reactions and fuel production. ${ }^{11,12,29-32}$

We have studied the electrochemical behaviour of a variety of cerium complexes, ${ }^{33,34}$ and found that, despite the isolated nature of the cerium $4 f^{1}$ electron, electron donating ligands shift the $\mathrm{Ce}(\mathrm{IV} / \mathrm{III})$ redox potential to reducing values, e.g. $E_{1 / 2}\left(\mathrm{Ce}^{\mathrm{IV} / \mathrm{III}}[2-\right.$ $\left.\left.\left({ }^{t} \mathrm{BuNO}\right) \mathrm{py}\right]_{4}\right)=-1.95 \mathrm{~V}$ vs. Fc/Fc ${ }^{+}$, where 2- $\left({ }^{t} \mathrm{BuNO}\right)$ py is $N$-tertbutyl- $N$-2-pyridylnitroxide. ${ }^{33,35}$ To further expand cerium redox

Roy and Diana T. Vagelos Laboratories, Department of Chemistry, University of Pennsylvania, 231 South $34^{\text {th }}$ St., Philadelphia, Pennsylvania 19104, USA. E-mail: schelter@sas.upenn.edu; Tel: +1 215-898-8633

$\dagger$ Electronic supplementary information (ESI) available: NMR spectra, UV-Vis spectra, FTIR spectra, Evans' method data, field dependence data, XAS spectra, electrochemical data, DFT coordinates and rendered molecular orbitals. CCDC 1404761-1404763. For ESI and crystallographic data in CIF or other electronic format see DOI: $10.1039 / \mathrm{c} 5 \mathrm{sc} 02607 \mathrm{e}$ chemistry we recently have focused on understanding the thermodynamic and kinetic factors that underlie cerium redox reactions. We demonstrated that in the cerium heterobimetallic frameworks, $\left[\mathrm{M}_{3}(\mathrm{THF})_{n}\right]\left[\mathrm{Ce}(\mathrm{BINOLate})_{3}\right] \mathrm{M}=\mathrm{Li}, \mathrm{Na}, \mathrm{K}$, Cs and BINOL $=(S)$-1,1'-bi-2-naphthol, the secondary coordination sphere, namely the identity of $\mathbf{M}^{+}$, impacted the rates and product outcomes of electron transfer (ET) reactions. ${ }^{36,37}$ Given these observations, we were compelled to investigate cerium heterobimetallic complexes with redox active ligands to express and modulate cerium-ligand intramolecular redox chemistry.

Herein, we report that the choice of alkali metal cation in the complexes $\mathrm{M}_{x}(\mathrm{py})_{y}\left[\mathrm{Ce}(\mathrm{PhNNPh})_{4}\right], \mathrm{M}=\mathrm{Li}, \mathrm{Na}$, and $\mathrm{K}, x=4$ (Li and $\mathrm{Na}$ ) or $5(\mathrm{~K})$, and $y=4(\mathrm{Li}), 8(\mathrm{Na})$, or $7(\mathrm{~K})$, resulted in variable electronic structures. Our results showed the smaller, harder alkali metal cations $\mathrm{Li}^{+}$and $\mathrm{Na}^{+}$stabilized the tetravalent cerium cation whereas the softer $\mathrm{K}^{+}$formed a cerium(III) complex. To the best of our knowledge, these results are the first examples of the use of secondary coordination sphere effects to modulate the oxidation state of a lanthanide cation.

\section{Results and discussion}

\section{Synthesis and structural characterization of 1-3}

Zdilla and coworkers recently reported $\mathrm{a} \mathrm{Li}^{+}$heterobimetallic diphenylhydrazido complex that effectively stabilized high valent $\mathrm{Mn}$ (Iv) cations despite the reducing character of the ligand and the oxidizing character of $\mathrm{Mn}(\mathrm{IV})$ (see Scheme 1). ${ }^{\mathbf{3 8 - 4 0}}$ Intrigued by these results and the relative scarcity of electrochemical properties reported for anionic nitrogen donors at cerium, ${ }^{41}$ we hypothesized that 1,2-diphenyl hydrazido ligands 

a. $\mathrm{MnCl}_{2}$
b. $\mathrm{Mn}\left[\mathrm{N}\left(\mathrm{SiMe}_{3}\right)_{2}\right]_{2}$
c. $\mathrm{Mn}(\mathrm{OAc})_{3}$
d. $\mathrm{MnF}_{3}$

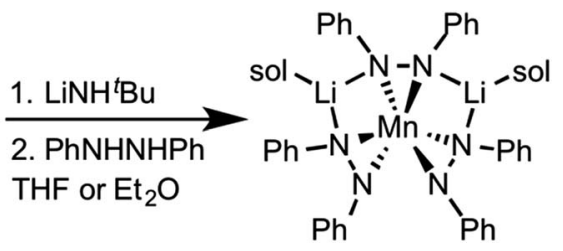

Scheme 1 Synthesis of the lithium manganese diphenylhydrazido complex. ${ }^{40}$

would similarly form cerium complexes with secondary structures governed by alkali metal cations.

Dark purple $\mathrm{Li}_{4}(\mathrm{py})_{4}\left[\mathrm{Ce}(\mathrm{PhNNPh})_{4}\right] \quad$ (1) and $\mathrm{Na}_{4}(\mathrm{py})_{8^{-}}$ $\left[\mathrm{Ce}(\mathrm{PhNNPh})_{4}\right]$ (2) were synthesized by layered reactions of $\mathrm{Ce}$ $\left[\mathrm{N}\left(\mathrm{SiMe}_{3}\right)_{2}\right]_{3}$ with 4 equiv. 1,2-diphenylhydrazine and 4 equiv. $\mathrm{MN}\left(\mathrm{SiMe}_{3}\right)_{2}, \mathrm{M}=\mathrm{Li}$ or $\mathrm{Na}$, in a mixture of $\mathrm{Et}_{2} \mathrm{O}$ and pyridine. The yields for $\mathbf{1}$ and 2 were $75 \%$ and $63 \%$ respectively (Scheme 2).

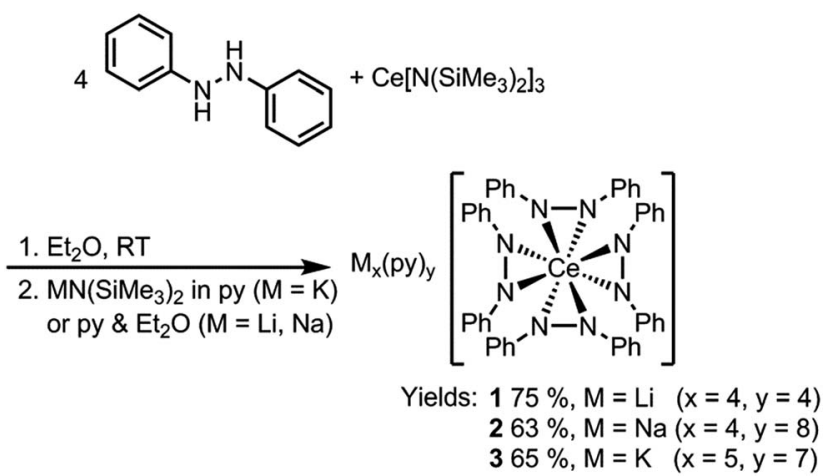

Scheme 2 Syntheses of complexes 1, 2, and 3 .
Because of the poor solubility of $\mathrm{K}_{5}(\mathrm{py})_{7}\left[\mathrm{Ce}(\mathrm{PhNNPh})_{4}\right]$ (3) in $\mathrm{Et}_{2} \mathrm{O}$-pyridine mixtures, 3 was prepared in neat pyridine by reaction of $\mathrm{Ce}\left[\mathrm{N}\left(\mathrm{SiMe}_{3}\right)_{2}\right]_{3}$ with 4 equiv. 1,2-diphenylhydrazine and 5 equiv. $\mathrm{KN}\left(\mathrm{SiMe}_{3}\right)_{2}$. Complex 3 was isolated as dark brown needles in $65 \%$ yield following crystallization from a concentrated pyridine solution of the reaction mixture layered with hexanes.

X-ray crystal structures revealed that $\mathbf{1}$ and $\mathbf{2}$ both formed formally Ce(Iv) complexes by charge balance, with four dianionic diphenylhydrazido ligands and four alkali metal cations per cerium cation in the formula unit (Fig. 1). Within the structures, the alkali metal cations bridged neighbouring 1,2-diphenylhydrazido units. Surprisingly, 3 formed an extended coordination polymer in which the potassium ions interacted both intramolecularly through bridging neighbouring hydrazido ligands and intermolecularly through $\mathrm{K}$-arene interactions within the ligands at $\mathrm{K}(4)$ and $\mathrm{K}(5)$ (Fig. 1). The most notable difference in the structure of $\mathbf{3}$, however, was the presence of an additional $\mathrm{K}^{+}$cation per formula unit, indicating that 3 was a formally $\mathrm{Ce}(\mathrm{III})$ complex.

The $\mathrm{N}-\mathrm{N}$ bond lengths in complexes 1,2 , and 3 were consistent with single bonds ranging from 1.451(2)-1.466(3) ̊ (Table 1). $\cdot^{39,42-46}$ The Ce-N distances for 1 ranged from 2.4199(13)-2.4408(14) Å while those for 2 were slightly shorter at 2.373(2)-2.398(2) (Table 1). The shortened Ce-N distances for 2 compared to 1 were consistent with the stronger Lewis acidity of $\mathrm{Li}^{+}$cations in 1 versus $\mathrm{Na}^{+}$cations in 2 . The $\mathrm{Li}^{+}$cations reduced the relative charge density at the nitrogen atoms for binding with the cerium cation, compared to the $\mathrm{Na}^{+}$cation in 2 . This effect was reversed in 3, however, with $\mathrm{Ce}-\mathrm{N}$ bonds ranging from 2.449(3)-2.636(4), in support of bonding to the larger

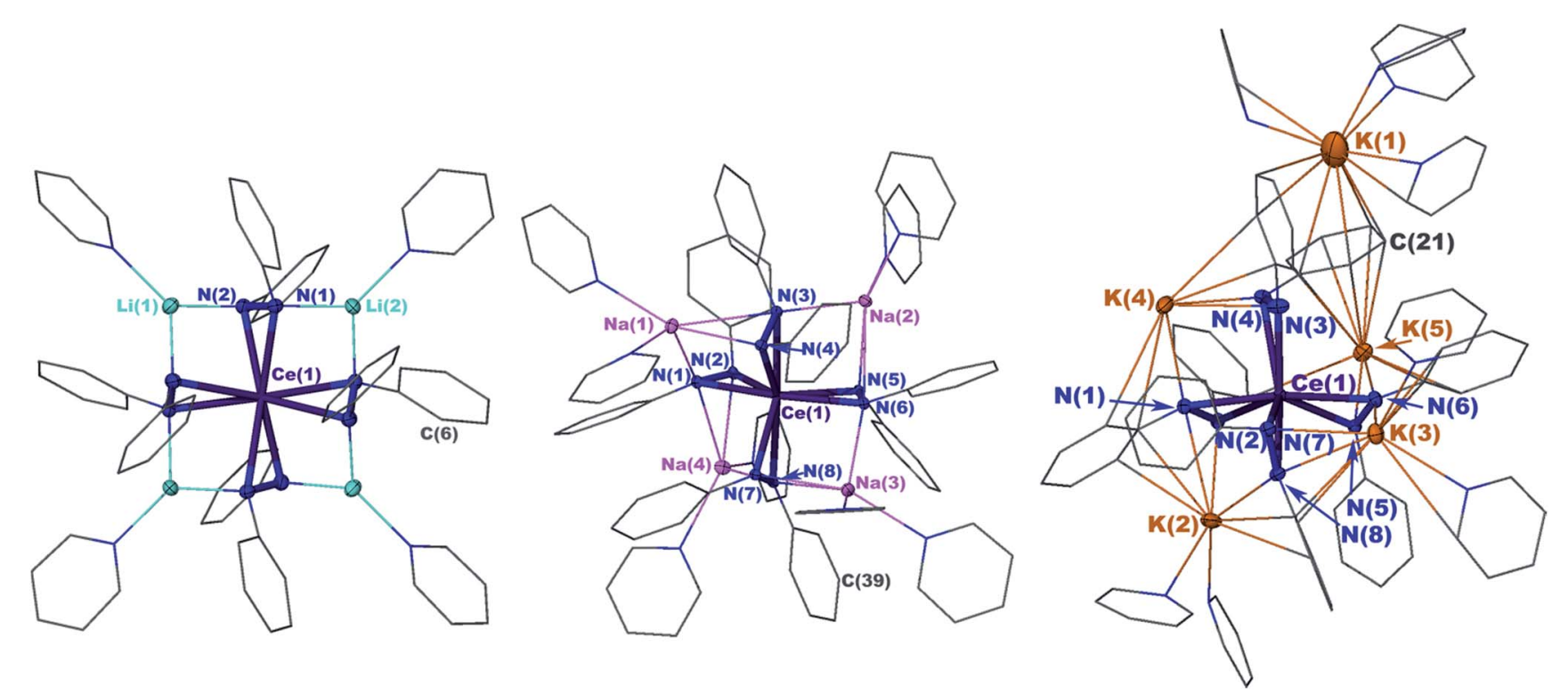

Fig. $130 \%$ probability thermal ellipsoid plots of $\mathrm{Li}_{4}(\mathrm{py})_{4}\left[\mathrm{Ce}(\mathrm{PhNNPh})_{4}\right]$ (1) (left), $\mathrm{Na}_{4}(\mathrm{py})_{8}\left[\mathrm{Ce}(\mathrm{PhNNPh})_{4}\right](2)(\mathrm{middle})_{,}$and $\mathrm{K}_{5}(\mathrm{py})_{7}\left[\mathrm{Ce}(\mathrm{PhNNPh})_{4}\right](3)$ (right) with the phenyl and pyridine rings shown in wire frame. Hydrogen atoms were omitted for clarity. Selected bond distances for 1 (Å): Ce(1)$\mathrm{N}(1)$ 2.4408(13), Ce(1)-N(2) 2.4199(13), N(1)-N(2) 1.451(2), Li(2)-N(1) 2.018(3), Li(2)-N(1') 2.018(3), Li(1) - N(2) 1.995(3). Selected bond distances for $2(\AA)$ : $\mathrm{Ce}(1)-\mathrm{N}(1) 2.390(3), \mathrm{Ce}(1)-\mathrm{N}(2) 2.373(2), \mathrm{N}(1)-\mathrm{N}(2) 1.462(3), \mathrm{Na}(1)-\mathrm{N}(1) 2.853(3), \mathrm{Na}(1)-\mathrm{N}(2) 2.630(3), \mathrm{Na}(1)-\mathrm{N}(3) 2.535(3) . \mathrm{Selected}$ bond distances for $3(\AA ̊)$ : $\mathrm{Ce}(1)-\mathrm{N}(1) 2.564(3), \mathrm{Ce}(1)-\mathrm{N}(2) 2.480(4), \mathrm{N}(1)-\mathrm{N}(2) 1.465(5), \mathrm{K}(2)-\mathrm{N}(1) 3.044(4), \mathrm{K}(2)-\mathrm{N}(2) 2.877(4)$. 
Table 1 Unique Ce(1) $-\mathrm{N}$ and $\mathrm{N}-\mathrm{N}$ bonds and the tabulation of $\tau_{4}$ parameters for complexes 1,2 , and 3 measured by X-ray crystallography or DFT calculations

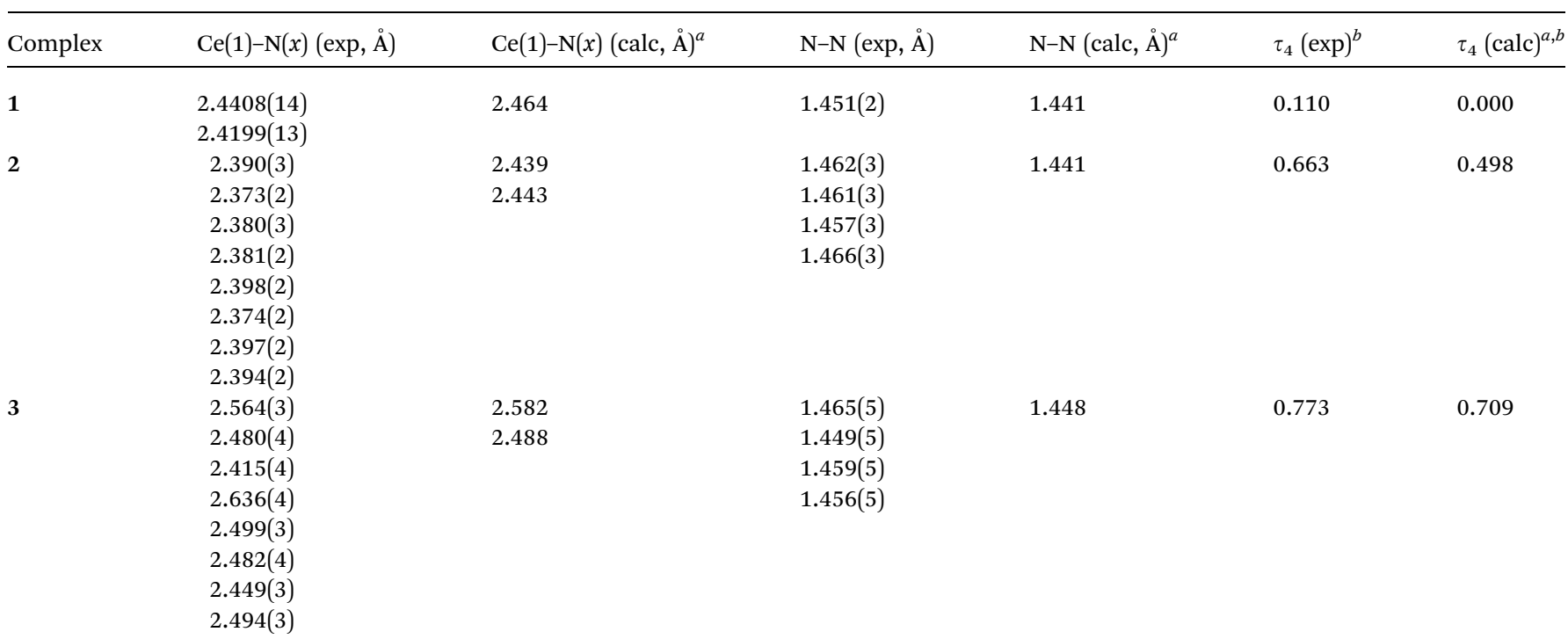

${ }^{a}$ Pyridine was replaced with $\mathrm{OMe}_{2}$ in the calculated structures, resulting in the following calculated complexes: $\mathrm{Li}_{4}(\mathrm{OMe})_{4}\left[\mathrm{Ce}(\mathrm{PhNNPh})_{4}\right]$, $\mathrm{Na}_{4}\left(\mathrm{OMe}_{2}\right)_{4}\left[\mathrm{Ce}(\mathrm{PhNNPh})_{4}\right]$, and $\mathrm{K}_{4}(\mathrm{OMe})_{4}\left[\mathrm{Ce}(\mathrm{PhNNPh})_{4}\right]^{-} .{ }^{b} \tau_{4}$ values were calculated using the angles formed from the centroids of the $\mathrm{N}-\mathrm{N}$ bonds and the cerium cations.

cerium(III) cation in that complex. This set of bond distances also indicated that a change in secondary coordination sphere caused a change in cerium electronic structure.

To better understand the structural differences between complexes 1-3, we established the geometrical changes to the Ce primary coordination sphere using shape parameters for eight coordinate complexes (Table S1, see the ESI $†$ ). ${ }^{47-49}$ The shape parameters showed that each structure could be described by distinct eight-coordinate geometries with complexes 1 and 2 resembling dodecahedra $\left(D_{2 \mathrm{~d}}\right)$, and complex 3 resembling a square antiprism $\left(D_{4 \mathrm{~d}}\right)$. However, complexes 1-3 were heavily distorted from the idealized structures described by shape parameters, which made it difficult to express the three-dimensional structural differences between each of the complexes. Because of the distortions, the parameter $\tau_{4}$, which typically indicated the degree of planarity in four-coordinate structures, was found to be a more convenient metric to describe the system (Fig. 1 and Table 1). ${ }^{50}$ The four centroids between the $\mathrm{N}-\mathrm{N}$ bonds of the ligands were used to calculate $\tau_{4}$ parameters for each complex, where a $\tau_{4}$ value of 0 indicated a planar distribution of the centroids and a value of 1 indicated a

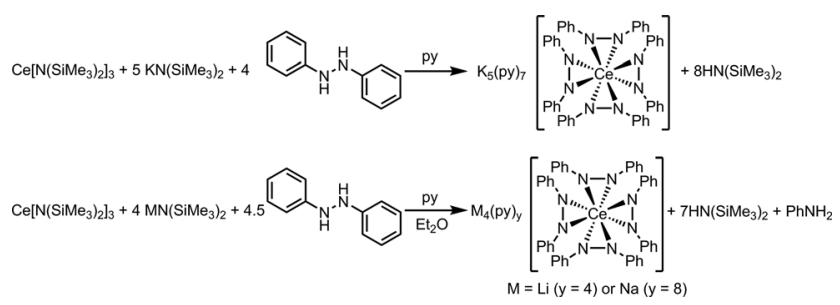

Scheme 3 The balanced chemical equation for the formation of 3 (top), and 1 and 2 (bottom). tetrahedral distribution of the centroids. ${ }^{50}$ The $\tau_{4}$ values revealed that as the ionic radius of the alkali metal cation increased, the geometry of the structure changed from pseudoplanar (1) $\tau_{4}=0.110$ to pseudo-tetrahedral (3) $\tau_{4}=0.773$ (Table 1 and Fig. 1).

We also examined the reaction mixtures of 1 and 2 by NMR spectroscopy for the reduction product from the spontaneous oxidation of $\mathrm{Ce}(\mathrm{III})$ to $\mathrm{Ce}(\mathrm{IV})$ (Scheme 3). Reductive cleavage of 1,2-diphenylhydrazine $\left(E_{1 / 2}=-1.7 \mathrm{~V} \text { versus } \mathrm{Fc} / \mathrm{Fc}^{+} \text {in DMSO }\right)^{51}$ by metal complexes, including f-block metals, has been established to yield aniline, metal anilides, and metal diphenylamides. ${ }^{38-40,52-62}$ We postulated the balanced equation in Scheme 3 was at work in the synthesis of complexes $\mathbf{1}$ and $\mathbf{2}$, where the electron transfer occurred from a Ce(III) cation to 0.5 equiv. 1,2-diphenylhydrazine to form aniline. ${ }^{40}$ Indeed, aniline was detected by ${ }^{1} \mathrm{H}$ NMR spectroscopy of the reaction mixture of complex 1 (see the ESI, Fig. S1-S4†). As expected, the reaction mixture for complex 3 did not show any evidence of aniline formation.

The reduction of 1,2-diphenylhydrazine by Ce(III) was surprising as the reduction potential of 1,2-diphenylhydrazine was thermodynamically inaccessible. ${ }^{3,51}$ However, coordination of substrates to one or more Lewis acids had been shown to promote electron transfer ${ }^{63-74}$ Fukuzumi and coworkers quantified the effect of Lewis acid coordination to $\mathrm{O}_{2}$ and its reduction with (TPP)Co (TPP $=$ tetra- $p$-tolylporphyrin). ${ }^{73}$ Similarly, the reduction of 1,2-diphenylhydrazine by $\mathrm{Ce}(\mathrm{III})$ in the formation of complexes 1-3 was determined to be dependent on the Lewis acidity of the countercation, where $\mathrm{K}^{+}$was not sufficiently Lewis acidic to promote the reduction of 1,2-diphenylhydrazine. 
Magnetic, spectroscopic, and electrochemical characterization

To investigate the valences of complexes 1-3, magnetism and Ce $\mathrm{L}_{\mathrm{III}}$-edge XAS spectroscopy studies were performed. The oxidation state of complex 3 was corroborated with room temperature magnetic susceptibility measurements using Evans' method ${ }^{75,76}$ and solid state SQUID magnetometry (Table S3 and Fig. S5-S7 in the ESI, $\dagger$ Fig. 2). The room temperature $\chi T$ products measured by both techniques, $\chi T=0.57 \mathrm{~cm}^{3} \mathrm{~K} \mathrm{~mol}^{-1}$ by Evans' method and $\chi T=0.70 \mathrm{~cm}^{3} \mathrm{~K} \mathrm{~mol}^{-1}$ by SQUID magnetometry, were similar to other reported $\mathrm{Ce}$ (III) complexes. ${ }^{77}$ Temperature dependent susceptibility plots of Ce(III) complexes typically show a decrease in the $\chi T$ product at low temperatures due to thermal depopulation of crystal field levels ${ }^{78-80}$ which was also observed in our data (Fig. 2). The low temperature $\chi T$ product was also similar to previously reported Ce(III) complexes. ${ }^{77}$ Complexes 1 and 2 showed only a small paramagnetic shift in solution when Evans' method was applied (0.01 ppm compared to $0.1 \mathrm{ppm}$ seen in complex 3 , see ESI, Table S3 $\dagger$ ). Similarly, the room temperature $\chi T$ products obtained by SQUID magnetometry were small, $\chi T=0.18 \mathrm{~cm}^{3} \mathrm{~K}$ $\mathrm{mol}^{-1}$ and $\chi T=0.089 \mathrm{~cm}^{3} \mathrm{~K} \mathrm{~mol}^{-1}$ for complexes 1 and 2 respectively (Fig. 2). The paramagnetic responses from complexes 1 and 2 were attributed to a small amount of paramagnetic impurity observed consistently over multiple measurements. Consistent with the magnetic data, the UV-Vis absorption spectra of $\mathbf{1}$ and $\mathbf{2}$ showed broad ligand-to-metal charge transfer bands, which are defining features in many $\mathrm{Ce}(\mathrm{Iv})$ complexes (Fig. S26-S27, ESI $\dagger$ ). ${ }^{36,81}$ Ce $\mathrm{L}_{\mathrm{III}}$-edge spectroscopic data were determined to be unreliable due to the instability of the complexes in the sample matrix (Fig. S8 $\dagger$ ).

IR spectroscopy was performed to probe the change in $\mathrm{N}-\mathrm{N}$ stretching frequency that was expected to accompany a change in formal oxidation state. We expected that the N-N stretching

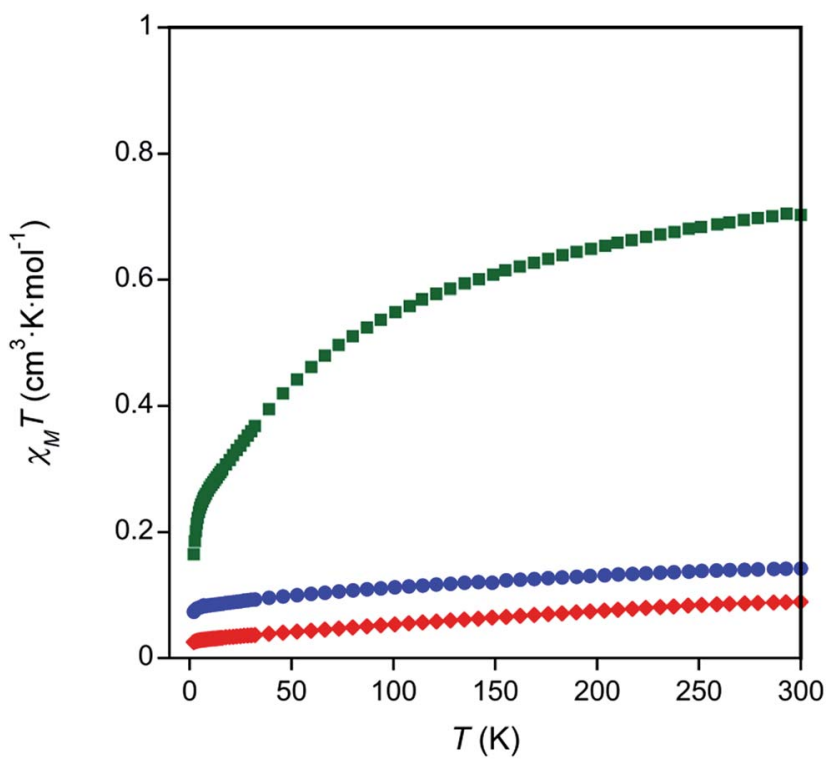

Fig. 2 Temperature dependent magnetic data for complexes 1 (blue circles), 2 (red diamonds), and 3 (green squares). modes would increase in energy from complex 1 to 3 based on the Lewis acidity of both the Ce ion and the alkali metal cation in each complex. Compared to Ce(III) cations, the more Lewis acidic $\mathrm{Ce}(\mathrm{Iv})$ cation was expected to accept more electron density through $\sigma$-bonding with the $\mathrm{N}-\mathrm{N}$ units, reducing the electron density in the $\mathrm{N}-\mathrm{N}$ bonds (see Fig. S38 in the ESI $\dagger$ ). We also expected the alkali metal cations would similarly withdraw more electron density with increasing Lewis acidity. DFT calculations were used to identify the vibrational modes in the experimental spectra (see DFT section for further details). DFT computed vibrational spectra typically overestimate the energies of the vibrational modes, ${ }^{\mathbf{8 2 - 8 6}}$ but apart from this overestimation, the calculated and experimental spectra were in good agreement (Table 2, see Fig. S23-S25 in the ESI $\dagger$ ).

The intense absorption band of the $\mathrm{N}-\mathrm{N}$ stretch in complexes 1, 2, and 3 in both the experimental and calculated spectra allowed for assignment of that vibrational mode (see ESI, Fig. S23-S25 $\dagger$ ). The Ce-N vibrational modes were difficult to unambiguously assign because of their low intensities and overlap with ligand features. Complex 3 showed a $\sim 10 \mathrm{~cm}^{-1}$ increase in energy of the $\mathrm{N}-\mathrm{N}$ stretching mode from complexes 1 and 2, consistent with a change in cerium oxidation state. Because the $\mathrm{N}-\mathrm{N}$ stretching mode found in complexes $\mathbf{1}$ and $\mathbf{2}$ differed by only $2 \mathrm{~cm}^{-1}$ despite the change in Lewis acidity between $\mathrm{Li}^{+}$and $\mathrm{Na}^{+}$, the more significant factor to the increase in energy between these complexes was evidently the oxidation state at the Ce cation. Overall, based on the spectroscopic and magnetic measurements, the oxidation state of the cerium metal centre was evidently impacted by the identity of the alkali metal cation in the secondary coordination sphere.

To better understand how the alkali metal cation in the secondary coordination sphere influenced the redox properties of the cerium metal centre, cyclic voltammetry was performed on complexes 1-3 (see Fig. S32-S37 in the ESI $\dagger$ ). Because of the instability of complexes $\mathbf{1}$ and $\mathbf{2}$ in coordinating solvents and the insolubility of complex $\mathbf{3}$ in non-coordinating solvents, the electrochemistry of complexes $\mathbf{1}$ and $\mathbf{2}$ was performed in fluorobenzene, and in THF for complex 3. Beginning the scans from the rest potentials in each case, the $\mathrm{Ce}^{\mathrm{IV} / \mathrm{III}}$ reduction waves (in the cases of $\mathbf{1}$ and 2) and oxidation wave (in the case of $\mathbf{3}$ ) were reversible for complexes 1-3, where the difference in the anodic and cathodic waves were $\Delta E=50 \mathrm{mV}$ for complex 3 in $\mathrm{THF}$, and $\Delta E=60-70 \mathrm{mV}$ for complexes 1 and 2 in

Table 2 Energies of the $\mathrm{N}-\mathrm{N}$ stretch vibrational modes of 1, 2, and 3 determined experimentally and by calculations. Spectrometer errors for the experimental spectra $= \pm 0.034 \mathrm{~cm}^{-1} .87$ The calculated values were not scaled, see text for details. ${ }^{82-86}$

\begin{tabular}{lll}
\hline Complex & $\begin{array}{l}\mathrm{N}-\mathrm{N} \text { stretch } \\
\left(\mathrm{cm}^{-1}, \mathrm{sol}=\mathrm{py}\right)\end{array}$ & $\begin{array}{l}\mathrm{N}-\mathrm{N} \text { stretch } \\
\left(\mathrm{cm}^{-1}, \mathrm{sol}=\mathrm{OMe}_{2}\right)\end{array}$ \\
\hline $\mathrm{Li}_{4}(\mathrm{sol})\left[\mathrm{Ce}(\mathrm{PhNNPh})_{4}\right](\mathbf{1})$ & 1255 & 1284 \\
$\mathrm{Na}_{4}(\mathrm{sol})\left[\mathrm{Ce}(\mathrm{PhNNPh})_{4}\right](2)$ & 1257 & 1289 \\
$\mathrm{~K}_{4}\left(\mathrm{OMe}_{2}\right)_{4}\left[\mathrm{Ce}(\mathrm{PhNNPh})_{4}\right]^{-}$ & - & 1303 \\
$(3-\mathrm{OMe}$ & & \\
$\left\{\mathrm{K}_{5}(\mathrm{py})_{7}\left[\mathrm{Ce}(\mathrm{PhNNPh})_{4}\right]\right\}_{n}(3)$ & 1265 & -
\end{tabular}


fluorobenzene. The electrochemical reversibility of the $\mathrm{Ce}$ IV/III redox event indicated that outer sphere electron transfer between cerium and the electrode was rapid in all three complexes, and that there was little ligand reorganization upon oxidation or reduction of the cerium cation in any geometry.

In order to compare the electrochemical potentials of complexes 1-3, we used 1,2-diphenylhydrazine, which was measured in both solvents, to normalize the influence of the solvent on the electron transfer between the electrode and the analyte. The $E_{1 / 2}$ values for the $\mathrm{Ce}^{\mathrm{IV} / \mathrm{III}}$ reduction of complexes 1 and 2 were centred at $-1.93 \mathrm{~V}$ and $-1.88 \mathrm{~V}$ versus $\mathrm{Fc} / \mathrm{Fc}^{+}$ respectively. Following the normalization for the difference in solvents, the $E_{1 / 2}$ of the $\mathrm{Ce}^{\mathrm{III} / \mathrm{IV}}$ oxidation of complex 3 was $-2.02 \mathrm{~V}$ versus $\mathrm{Fc} / \mathrm{Fc}^{+}$. The negative reduction potentials indicated that the Ce(Iv) oxidation state was strongly stabilized by the hard, anionic $\mathrm{PhNNPh}^{2-}$ ligand. Use of electron-rich anionic N-donors had been shown to support the Ce(Iv) oxidation state previously. ${ }^{33}$ Thus, despite its measurement as a slightly more potent reductant than $\mathbf{1}$ and 2 , complex $\mathbf{3}$ was isolated as a $\mathrm{Ce}(\mathrm{III})$ complex.

\section{$\mathrm{Ce}(\mathrm{Iv})$ and cation exchange reactions}

Considering the oxidation potential of complex 3 , we reasoned a potassium-supported Ce(Iv) diphenylhydrazido analogue should be accessible. In an effort to isolate a Ce(Iv) diphenylhydrazido complex with $\mathrm{K}^{+}$cations in the secondary coordination sphere, we reacted 1,2-diphenylhydrazine with a formally $\mathrm{Ce}(\mathrm{Iv})$ protonolysis starting material, Ce $\left[\mathrm{N}\left(\mathrm{SiHMe}_{2}\right)_{2}\right]_{4} \cdot{ }^{88,89}$ The addition of 1,2-diphenylhydrazine to the $\mathrm{Ce}(\mathrm{Iv})$ starting material, however, resulted in immediate reduction (Scheme 4) and subsequent reaction with $\mathrm{KN}\left(\mathrm{SiMe}_{3}\right)_{2}$ formed complex 3, which was detected by ${ }^{1} \mathrm{H}$ NMR spectroscopy. Adding 1,2-diphenylhydrazine to a mixture of $\mathrm{KH}$ and Ce $\left[\mathrm{N}\left(\mathrm{SiHMe}_{2}\right)_{2}\right]_{4}$ also resulted in the formation of complex 3 . Presumably, 0.5 equiv. azobenzene was the other product that formed in the course of the redox reaction, but this side product was not detected by ${ }^{1} \mathrm{H}$ NMR spectroscopy (see Fig. S22, ESI $\dagger$ ). Thus, the presence of alkali metal cations in the secondary coordination sphere were essential in stabilizing the Ce(Iv) oxidation state. The alkali metals in solution structurally supported the resultant cerium diphenylhydrazido complex as well as modulated the electronics of the ligands in order to stabilize $\mathrm{Ce}(\mathrm{Iv})$ and destabilize the ligand oxidation. These observations were consistent with those of Zdilla and coworkers, who disclosed that, upon removing the $\mathrm{Li}^{+}$cations in the cluster $\mathrm{Li}_{4} \mathrm{Mn}_{4}\left(\mu_{3}-\mathrm{N}^{t} \mathrm{Bu}\right)_{3}\left(\mathrm{~N}^{t} \mathrm{Bu}\right)(\mathrm{N})$, the $\mathrm{Mn}(\mathrm{v})$ cations reductively eliminated azo-tert-butane. ${ }^{\mathbf{9 0}}$

Based on the similar cerium electrochemistry of complexes 1 and 3 and the $\mathrm{Ce}-\mathrm{N}$ and $\mathrm{M}-\mathrm{N}\left(\mathrm{M}=\mathrm{Li}^{+}\right.$and $\left.\mathrm{K}^{+}\right)$bond enthalpies, we expected that complex 3 should convert to complex $\mathbf{1}$ through a cation exchange reaction (Scheme 5). The successful metathesis of LiI with complex 3 in diethyl ether demonstrated that the oxidation state of cerium could be influenced by a change in the secondary coordination sphere (Fig. S15, ESI $\dagger$ ). This reaction likely occurred through a $\mathrm{Li}^{+}$promoted reduction of the 1,2-diphenylhydrazido ligand as well. By ${ }^{1} \mathrm{H}$ NMR

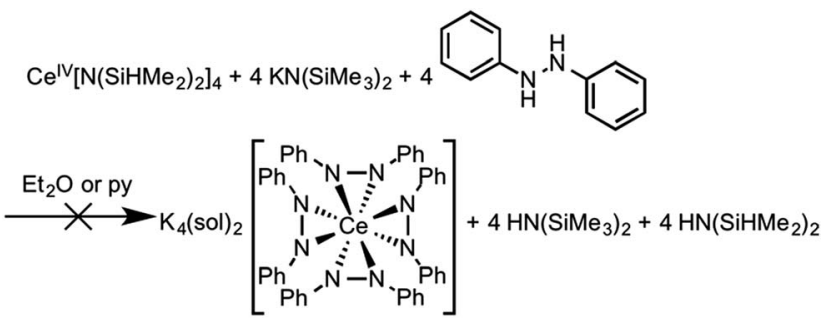

Scheme 4 Attempted synthesis of $\mathrm{K}_{4}(\mathrm{sol})_{2}\left[\mathrm{Ce}(\mathrm{PhNNPh})_{4}\right]$ starting from a Ce(Iv) precursor. Instead, $\mathrm{K}_{5}(\mathrm{py})_{7}\left[\mathrm{Ce}(\mathrm{PhNNPh})_{4}\right]$ (3) formed as a result of this reaction (Fig. S22, ESI†).

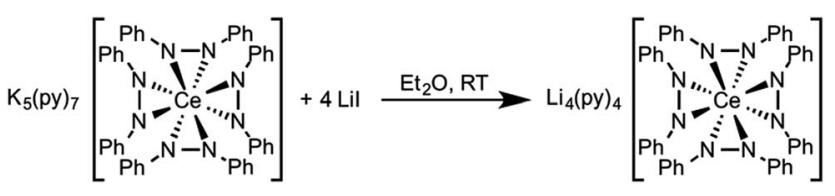

Scheme 5 Metathesis reaction of complex 3 with 4 equiv. of Lil.

spectroscopy, the reaction appeared to proceed cleanly, but the percent conversion was consistently overestimated. Presumably the resonances of side-products present in the reaction overlapped with the desired products' resonances. Cation exchange reactions of 2 with KI were also successful, where complex 3 was the only product evident by ${ }^{1} \mathrm{H}$ NMR spectroscopy (Fig. S20-S21 in the ESI $\dagger$ ). In this case, the 1,2-diphenylhydrazido evidently acted as the reductant to form $\mathrm{Ce}(\mathrm{III})$ and azobenzene. A complex mixture formed when cation exchange of complex 1 with KI was attempted (Fig. S17-S19†). The complex mixture observed in this reaction could be as a result of the smaller lattice energy of LiI formation, the poorer solubility of KI, and the weaker $\mathrm{M}-\mathrm{N}$ interaction with larger alkali metal cations. ${ }^{\mathbf{9 1 , 9 2}}$

\section{Conclusions}

We have shown that the secondary coordination sphere about cerium 1,2-diphenylhydrazido complexes influenced both the primary coordination geometry and the oxidation state of the cerium metal centre, making these complexes the first example of a secondary coordination sphere influencing the oxidation state of f-element complexes. The alkali metals in the secondary coordination sphere both facilitated the reduction of the 1,2-diphenylhydrazine to produce a high-valent Ce(Iv) complex, and structurally stabilized the high-valent Ce(Iv) complexes. Furthermore, a cation exchange reaction with simple alkali metal salts had changed the oxidation state at the cerium ion. The use of multiple Lewis acids could be a general strategy to access high valent metal oxidation states. Electronic and steric changes to the primary coordination sphere in this system are currently under investigation.

\section{Experimental section}

\section{General methods}

Unless otherwise indicated all reactions and manipulations were performed under an inert atmosphere $\left(\mathrm{N}_{2}\right)$ using standard 
Schlenk techniques or in a Vacuum Atmospheres, Inc. Nexus II drybox equipped with a molecular sieves 13X/Q5 Cu-0226S catalyst purifier system. Glassware was oven-dried overnight at $150{ }^{\circ} \mathrm{C}$ prior to use. ${ }^{1} \mathrm{H},{ }^{13} \mathrm{C}$, and ${ }^{7} \mathrm{Li}$ NMR spectra were obtained on a Bruker DMX-300, on a Bruker DMX-360, or on a Bruker DRX-400 Fourier transform NMR spectrometer at 300, 360, and $400 \mathrm{MHz}$ respectively. Chemical shifts were recorded in units of parts per million downfield from residual proteo solvent peaks $\left({ }^{1} \mathrm{H}\right)$, or characteristic solvent peaks $\left({ }^{13} \mathrm{C}\right)$. The ${ }^{7} \mathrm{Li}$ spectra were referenced to external solution standards of $\mathrm{LiCl}$ in $\mathrm{H}_{2} \mathrm{O}$. Evans' method was performed on a Bruker BioDRX-500 Fourier transform NMR spectrometer at $500 \mathrm{MHz}$. Hexamethylcyclotrisiloxane was used as the internal standard for Evans's method experiments. Elemental analyses were performed at the University of California, Berkeley Microanalytical Facility using a Perkin-Elmer Series II 2400 CHNS analyzer. UV-vis-NIR absorption measurements of complexes were performed using a PerkinElmer 950 UV-vis/NIR Spectrophotometer. One mm path length screw cap quartz cells were used with a blank measured before each run. The infrared spectra were obtained from 400-4000 $\mathrm{cm}^{-1}$ using a PerkinElmer 1600 series infrared spectrometer. FTIR solution spectra were first collected with a background of air, and then the solvent spectrum was subtracted using PerkinElmer software. GC/MS Spectrometry was performed using an Agilent 5937 GC/MS spectrometer with the CI method of ionization. Diethyl ether was used as the volatile solvent and $\mathrm{He}$ as the carrier gas.

\section{Materials}

Tetrahydrofuran, diethyl ether, hexane, fluorobenzene, and pentane were purchased from Fisher Scientific. The solvents were sparged for $20 \mathrm{~min}$ with dry $\mathrm{N}_{2}$ and dried using a commercial two-column solvent purification system comprising columns packed with Q5 reactant and neutral alumina respectively (for hexane and pentane), or two columns of neutral alumina (for THF, diethyl ether, and fluorobenzene). Pyridine, also purchased from Fisher Scientific, was freeze-pumpthawed for 4 cycles and stored over $4 \AA$ molecular sieves for three days before use. Deuterated solvents were purchased from Cambridge Isotope Laboratories, Inc. Pyridine- $d_{5}$ was stored over $4 \AA$ molecular sieves for three days before use, and benzene- $d_{6}$ was dried and stored over potassium for 2 days before use. $\mathrm{Ce}\left[\mathrm{N}\left(\mathrm{SiMe}_{3}\right)_{2}\right]_{3}{ }^{\mathbf{9 3}}$ and $\mathrm{Ce}\left[\mathrm{N}\left(\mathrm{SiHMe}_{2}\right)_{2}\right]_{4}{ }^{\mathbf{8 8 , 8 9}}$ were prepared following published procedures. $\mathrm{Li}\left[\mathrm{N}\left(\mathrm{SiMe}_{3}\right)_{2}\right]$ (Acros) was recrystallized from hot pentane prior to use. $\mathrm{K}\left[\mathrm{N}\left(\mathrm{SiMe}_{3}\right)_{2}\right]$ (Acros) and $\mathrm{Na}\left[\mathrm{N}\left(\mathrm{SiMe}_{3}\right)_{2}\right]$ (Acros) were used as purchased. Hydrazobenzene (Sigma Aldrich, MP Biochemicals, Alfa Aesar) was sublimed under reduced pressure first at $60{ }^{\circ} \mathrm{C}$ to remove azobenzene, and then at $105^{\circ} \mathrm{C}$ for further purification prior to use. Alternatively, the hydrazobenzene was purified by fractional recrystallization of hydrazobenzene dissolved in toluene and layered with pentane.

\section{Electrochemistry}

Voltammetry experiments (CV and DPV) were performed using a $\mathrm{CH}$ Instruments 620D Electrochemical Analyzer/Workstation and the data were processed using CHI software v 9.24. All experiments were performed in an $\mathrm{N}_{2}$ atmosphere drybox using electrochemical cells that consisted of a $4 \mathrm{~mL}$ vial, glassy carbon (3 mm diameter) working electrode, a platinum wire counter electrode, and a silver wire plated with $\mathrm{AgCl}$ as a quasi-reference electrode. The working electrode surfaces were polished prior to each set of experiments, and were periodically replaced to prevent the build-up of oxidized product on the electrode surfaces. Potentials were reported versus ferrocene (Fc), which was converted from cobaltocene for calibration at the end of each run. ${ }^{3}$ Solutions employed during CV studies were $\sim 3 \mathrm{mM}$ in analyte. For electrochemistry collected in fluorobenzene, the solution was $100 \mathrm{mM}$ in $\left[{ }^{n} \mathrm{Bu}_{4} \mathrm{~N}\right]\left[\mathrm{B}\left(3,5-\left(\mathrm{CF}_{3}\right)_{2}-\mathrm{C}_{6} \mathrm{H}_{3}\right)_{4}\right]\left(\left[{ }^{n} \mathrm{Bu}_{4} \mathrm{~N}\right]-\right.$ $\left.\left[\mathrm{BAr}_{4}{ }_{4}\right]\right)$, and electrochemistry collected in THF had $100 \mathrm{mM}$ in $\left[{ }^{n} \operatorname{Pr}_{4} \mathrm{~N}\right]\left[\mathrm{B}\left(3,5-\left(\mathrm{CF}_{3}\right)_{2}-\mathrm{C}_{6} \mathrm{H}_{3}\right)_{4}\right]\left(\left[{ }^{n} \operatorname{Pr}_{4} \mathrm{~N}\right]\left[\mathrm{BAr}^{\mathrm{F}}{ }_{4}\right]\right)$ as the electrolyte. All data were collected in a positive-feedback IR compensation mode. Scan rate dependences of $25-1000 \mathrm{mV} \mathrm{s}^{-1}$ were performed to determine electrochemical reversibility.

\section{Magnetism}

Magnetic data were collected on a Quantum Design MultiProperty Measurement System (MPMS-7) with a Reciprocating Sample Option at $1 \mathrm{~T}$ from 2 to $300 \mathrm{~K}$ and at $2 \mathrm{~K}$ and $300 \mathrm{~K}$ from 0 to $7 \mathrm{~T}$. Quartz wool was dried at $250{ }^{\circ} \mathrm{C}$ prior to use, plastic drinking straws were evacuated overnight prior to use. The plastic drinking straws themselves were used as the sample holders through heat sealing the plastic tubing. The plastic drinking straws were heat sealed at one end in a glovebox. Then a ground sample was loaded into the straw and capped with $\sim 10 \mathrm{mg}$ of quartz wool. The other end of the plastic drinking straw was then sealed through application of heat, forming a pouch that contained the sample and the quartz wool. The sample and wool were weighed to the nearest $0.1 \mathrm{mg}$ on a calibrated and levelled Mettler-Toledo AL-204 analytical balance. Corrections for the intrinsic diamagnetism of the samples were made using Pascal's constants. ${ }^{94}$ Data were collected on two independently prepared samples to ensure reproducibility.

\section{X-ray absorption spectroscopy}

Ce $\mathrm{L}_{\mathrm{III}}$-edge XANES data were collected at the Stanford Synchrotron Radiation Lightsource, beamline 11-2, using a $\mathrm{Si}$ 220 (phi =0) double monochromator that was detuned to $20 \%$ in order to reduce harmonic contamination. The resulting data have an energy resolution of $3.2 \mathrm{eV}$. Data were collected in transmission, using a $\mathrm{CeO}_{2}$ reference to calibrate the energy scale, setting the first inflection point of the $\mathrm{CeO}_{2}$ absorption to $5723 \mathrm{eV}$. A linear pre-edge background was subtracted and the data were subsequently normalized at $5800 \mathrm{eV}$.

Since the compounds are extremely sensitive to oxygen, each sample was ground into a powder, mixed with dry boron nitride as a diluent, and then packed into the slots of a machined aluminum sample holder. Aluminized mylar was affixed to the holder with an indium-wire seal. After packaging, the samples were transported in dry nitrogen-filled containers to the beamline. Sample holders were quickly transferred to the 
vacuum chamber, exposing the sealed holders to air for less than thirty seconds before pumping out the chamber and collecting the data under vacuum.

\section{X-ray crystallography}

X-ray intensity data were collected on a Bruker APEXII CCD area detector employing graphite-monochromated Mo-K $\alpha$ radiation $(\lambda=0.71073 \AA)$ at a temperature of $143(1) \mathrm{K}$. In all cases, rotation frames were integrated using SAINT, ${ }^{95}$ producing a listing of unaveraged $F^{2}$ and $\sigma\left(F^{2}\right)$ values which were then passed to the SHELXTL ${ }^{96}$ program package for further processing and structure solution on a Dell Pentium 4 computer. The intensity data were corrected for Lorentz and polarization effects and for absorption using TWINABS ${ }^{97}$ or SADABS. ${ }^{98}$ The structures were solved by direct methods (SHELXS-97) ${ }^{99}$ Refinement was by fullmatrix least squares based on $F^{2}$ using SHELXL-97. ${ }^{99}$ All reflections were used during refinements. The weighting scheme used was $w=1 /\left[\sigma^{2}\left(F_{\mathrm{o}}{ }^{2}\right)+(0.0907 P)^{2}+0.3133 P\right]$ where $P=\left(F_{\mathrm{o}}{ }^{2}+\right.$ $\left.2 F_{\mathrm{c}}^{2}\right) / 3$. Non-hydrogen atoms were refined anisotropically and hydrogen atoms were refined using a riding model. Complex 1 $\left(\mathrm{Li}_{4}(\mathrm{py})_{4}\left[\mathrm{Ce}(\mathrm{PhNNPh})_{4}\right] \quad \mathrm{C}_{68} \mathrm{H}_{60} \mathrm{~N}_{12} \mathrm{Li}_{4} \mathrm{Ce}\right)$, crystallizes in the orthorhombic space group Fddd with $a=11.4483(7) \AA, b=$ 43.060(2) $\AA, c=24.5220(14) \AA, V=12088.5(12) \AA^{3}, Z=8$, and $d_{\text {calc }}=1.333 \mathrm{~g} \mathrm{~cm}^{-3}$. A total of 74593 reflections were measured yielding 3485 unique reflections $\left(R_{\text {int }}=0.0381\right)$. Complex 2 $\left(\mathrm{Na}_{4}(\mathrm{py})_{8}\left[\mathrm{Ce}(\mathrm{PhNNPh})_{4}\right] \mathrm{C}_{88} \mathrm{H}_{80} \mathrm{~N}_{16} \mathrm{Na}_{4} \mathrm{Ce}\right)$ crystallizes in the triclinic space group $P \overline{1}$ with $a=13.9504(7) \AA, b=16.2467(9) \AA$, $c=19.0053(11) \AA, \alpha=83.136(3)^{\circ}, \beta=83.696(3)^{\circ}, \gamma=84.993(3)^{\circ}$, $V=4238.8(4) \AA^{3}, Z=2$, and $d_{\text {calc }}=1.249 \mathrm{~g} \mathrm{~cm}^{-3}$. A total of 147398 reflections were measured, 19328 of them unique reflections $\left(R_{\text {int }}=0.0680\right)$. Complex $3\left(\mathrm{~K}_{5}(\mathrm{py})_{7}\left[\mathrm{Ce}(\mathrm{PhNNPh})_{4}\right]\right)$ $\mathrm{C}_{83} \mathrm{H}_{75} \mathrm{~N}_{15} \mathrm{~K}_{5} \mathrm{Ce}$, crystallizes in the triclinic space group $P \overline{1}$ with $a=15.2003(12) \AA, b=15.4668(12) \AA, c=18.0353(15) \AA, \alpha=$ 93.849(5) $, \beta=101.333(5)^{\circ}, \gamma=107.292(5)^{\circ}, V=3933.7(5) \AA^{3}$, $Z=2$, and $d_{\text {calc }}=1.366 \mathrm{~g} \mathrm{~cm}^{-3}$. A total of 95153 reflections were measured yielding 17890 unique reflections $\left(R_{\mathrm{int}}=0.0544\right)$.

\section{Computational details}

All calculations were performed with Gaussian 09 Revision D.01 ${ }^{100}$ with the B3LYP hybrid DFT method. A 28-electron small core effective core potential was applied to cerium with published segmented natural orbital basis set incorporating quasirelativistic effects, ${ }^{101-103}$ while the 6-31 $\mathrm{G}^{*}$ basis set was applied to all other atoms. Geometry optimizations of $\mathbf{1}$ and $\mathbf{2}$ were based on their crystal structures, while the geometry optimization of the Ce(rv) structure of 3 was based off of the crystal structure coordinates of complex 2 . The coordinates that were input for the geometry optimizations of the anionic Ce(III) analogues were based on the optimized geometry found for the $\mathrm{Ce}(\mathrm{Iv})$ calculations $\mathbf{1}, 2$, and 3 with elongated $\mathrm{Ce}-\mathrm{N}$ bonds. Geometry optimization was attempted with pyridine solvating the alkali metals. However, convergence could not be reached with this system. No other restrictions were placed on the systems besides the spin. All frequency calculations found no negative frequencies, except for the calculation of $\mathrm{Li}_{4}\left(\mathrm{OMe}_{2}\right)_{4}\left[\mathrm{Ce}(\mathrm{PhNNPh})_{4}\right]$ which had 4 small negative frequencies less than $-17 \mathrm{~cm}^{-1}$, indicating that the optimized structures found were at an energy minimum. Molecular orbitals were rendered using Chemcraft v. 1.6. ${ }^{104}$

\section{Synthetic details and characterization}

Synthesis of $\mathrm{Li}_{4}(\mathrm{py})_{4}\left[\mathrm{Ce}(\mathbf{P h N N P h})_{4}\right]$ (1). Hydrazobenzene $(0.083 \mathrm{~g}, 0.45 \mathrm{mmol})$ was dissolved in $3 \mathrm{~mL}$ of diethyl ether in a $20 \mathrm{~mL}$ scintillation vial. $\mathrm{Ce}\left[\mathrm{N}\left(\mathrm{SiMe}_{3}\right)_{2}\right]_{3} \bullet$ toluene $(0.082 \mathrm{~g}$, $0.12 \mathrm{mmol}$ ) was added to the mixture, resulting in a brownorange suspension. After stirring for $1 \mathrm{~h}$, the diethyl ether was removed under reduced pressure. Diethyl ether (or toluene) ( $5 \mathrm{~mL}$ ) with pyridine ( $43 \mu \mathrm{L}, 4.5$ equiv.) was added to the greenyellow solid, resulting in an orange suspension. In a separate $20 \mathrm{~mL}$ scintillation vial, $\mathrm{LiN}\left(\mathrm{SiMe}_{3}\right)_{2}(0.076 \mathrm{~g}, 0.45 \mathrm{mmol})$ was weighed and dissolved in hexanes to form a colourless solution. The colourless hexanes solution was layered over the orange suspension. Product formation was concentration-dependent, but not stoichiometry dependent. The product could also be formed using bulk reactions but crystalline yield was lower. After 1 day, dark purple crystals formed. The crystals were collected by filtration over a medium frit, washed with hexane, and dried under reduced pressure. Yield: $0.103 \mathrm{~g}, 0.085 \mathrm{mmol}$, 74\%. ${ }^{1} \mathrm{H}$ NMR $\left(360 \mathrm{MHz}, \mathrm{C}_{6} \mathrm{D}_{6}\right) \delta 7.93(\mathrm{~s}, 2 \mathrm{H}), 7.26(\mathrm{~s}, 4 \mathrm{H}), 6.69$ $(\mathrm{t}, J=7.2 \mathrm{~Hz}, 1 \mathrm{H}), 6.49(\mathrm{t}, J=7.2 \mathrm{~Hz}, 2 \mathrm{H}), 6.36(\mathrm{~s}, 2 \mathrm{H}), 6.23(\mathrm{~s}$, $4 \mathrm{H}), 3.13(\mathrm{q}, J=7.0 \mathrm{~Hz}, 2 \mathrm{H}), 0.88(\mathrm{t}, J=7.0 \mathrm{~Hz}, 3 \mathrm{H}) .{ }^{7} \mathrm{Li} \mathrm{NMR}$ $\left(400 \mathrm{MHz}, \mathrm{C}_{6} \mathrm{D}_{6}\right) \delta 1.93(0.2 \mathrm{Li}), 1.47(1 \mathrm{Li}) .{ }^{13} \mathrm{C}$ NMR $(360 \mathrm{MHz}$, $\left.\mathrm{C}_{6} \mathrm{D}_{6}\right) \delta 160.86,149.31,136.76,129.36,124.14,118.49,117.07$. FTIR $\left(\mathrm{C}_{6} \mathrm{D}_{6}\right)$ 3055.63, 2976.81, 2828.47, 2867.82, 1584.84 (vs), 1556.91, 1471.46 (vs), 1442.30 (s), 1416.36, 1296.71, 1286.64, 1254.62 (vs), 1164.28, 1118.78, 1071.37, 1026.25, 1019.52, 987.41, 869.14, 775.61, $751.14(\mathrm{~s}), 702.66$ (s), 693.13 (s), 618.17. Elemental analysis calculated for $\mathrm{Li}_{4}\left(\mathrm{py}_{3}\left(\mathrm{Et}_{2} \mathrm{O}\right)\left[\mathrm{Ce}(\mathrm{PhNNPh})_{4}\right]\right.$ $\mathrm{C}_{67} \mathrm{H}_{65} \mathrm{CeLi}_{4} \mathrm{~N}_{11} \mathrm{O}: \mathrm{C}, 66.61 ; \mathrm{H}, 5.42 ; \mathrm{N}, 12.75$. Found: $\mathrm{C}, 66.36$; $\mathrm{H}, 5.39 ; \mathrm{N}, 12.61 \%$.

Synthesis of $\mathbf{N a}_{4}(\mathbf{p y})_{8}\left[\mathrm{Ce}(\mathbf{P h N N P h})_{4}\right]$ (2). Hydrazobenzene $(0.095 \mathrm{~g}, 0.52 \mathrm{mmol})$ was dissolved in $4 \mathrm{~mL}$ of diethyl ether in a $20 \mathrm{~mL}$ scintillation vial. $\mathrm{Ce}\left[\mathrm{N}\left(\mathrm{SiMe}_{3}\right)_{2}\right]_{3}(0.082 \mathrm{~g}, 0.13 \mathrm{mmol})$ was added to the mixture, resulting in a brown-orange suspension. After stirring for $1 \mathrm{~h}$, the diethyl ether was removed under reduced pressure. Diethyl ether $(2 \mathrm{~mL})$ was added to the greenyellow solid, and then pyridine ( $105 \mu \mathrm{L}, 10$ equiv.) was added to form an orange suspension. $\mathrm{NaN}\left(\mathrm{SiMe}_{3}\right)_{2}(0.095 \mathrm{~g}, 0.52 \mathrm{mmol})$ was weighed in a separate $20 \mathrm{~mL}$ scintillation vial and dissolved in $1.5 \mathrm{~mL}$ diethyl ether. The dissolved $\mathrm{NaN}\left(\mathrm{SiMe}_{3}\right)_{2}$ was layered over the orange suspension. Finally, hexanes $(1 \mathrm{~mL})$ were layered over the two diethyl ether layers. $0.132 \mathrm{~g}(0.083 \mathrm{mmol})$ of purple needles were collected by filtration in a medium frit, washed with hexanes, and dried under reduced pressure. Product formation was concentration-sensitive but not stoichiometry sensitive. The product could also be formed using bulk reactions but crystalline yield was lower. Yield: $64 \% .{ }^{1} \mathrm{H}$ NMR $\left(360 \mathrm{MHz}, \mathrm{C}_{6} \mathrm{D}_{6}\right) \delta 8.04(\mathrm{~s}, 2 \mathrm{H}), 7.05(\mathrm{~s}, 2 \mathrm{H}), 6.88(\mathrm{t}, J=7.2 \mathrm{~Hz}$, $1 \mathrm{H}), 6.76-6.52(\mathrm{~m}, 2 \mathrm{H}), 6.51-6.14(\mathrm{~m}, 2 \mathrm{H}), 5.89(\mathrm{~s}, 1 \mathrm{H}), 3.21(\mathrm{q}, J$ $=7.0 \mathrm{~Hz}, 0.6 \mathrm{H}), 1.06(\mathrm{t}, J=7.0 \mathrm{~Hz}, 1 \mathrm{H}) .{ }^{13} \mathrm{C}$ NMR $(360 \mathrm{MHz}$, $\left.\mathrm{C}_{6} \mathrm{D}_{6}\right)$ 161.23, 150.53, 136.39, 129.07, 124.04, 113.48. FTIR $\left(\mathrm{C}_{6} \mathrm{D}_{6}\right)$ 3052.20, 2997.57, 2976.29, $22868.66,1582.74$ (vs), 
1547.75 (s), 1468.83 (vs), 1440.44 (s), 1296.41 (s), 1289.19 (s), 1256.80 (vs), 1162.99 (s), 1148.41, 1118.74, 1069.80, 1033.85, 1018.29, 987.09 (vs), 860.03 (s), 793.83, 746.86 (s), 702.93 (vs), $613.74,599.51$. Elemental analysis calculated for $\mathrm{Na}_{4}(\mathrm{py})_{5}\left(\mathrm{Et}_{2} \mathrm{O}\right)$ $\left[\mathrm{Ce}(\mathrm{PhNNPh})_{4}\right] \mathrm{C}_{77} \mathrm{H}_{75} \mathrm{CeNa}_{4} \mathrm{~N}_{13} \mathrm{O}: \mathrm{C}, 64.65 ; \mathrm{H}, 5.28 ; \mathrm{N}, 12.73$. Found: C, 64.58; H, 5.08; N, 12.70\%.

Synthesis of $\mathbf{K}_{5}(\mathbf{p y})_{7}\left[\mathrm{Ce}(\mathbf{P h N N P h})_{4}\right]$ (3). Hydrazobenzene $(0.095 \mathrm{~g}, 0.52 \mathrm{mmol}$ ) was dissolved in $4 \mathrm{~mL}$ of diethyl ether in a $20 \mathrm{~mL}$ scintillation vial. $\mathrm{Ce}\left[\mathrm{N}\left(\mathrm{SiMe}_{3}\right)_{2}\right]_{3}(0.081 \mathrm{~g}, 0.13 \mathrm{mmol})$ was added to the mixture, resulting in a brown-orange suspension. After stirring for $1 \mathrm{~h}$, the diethyl ether was removed under reduced pressure. Pyridine was added to the green-yellow solid, resulting in a dark red solution, which over time formed a red suspension. $\mathrm{KN}\left(\mathrm{SiMe}_{3}\right)_{2}(0.124 \mathrm{~g}, 0.64 \mathrm{mmol})$ was weighed and added to the pyridine solution. A dark brown solution immediately formed. The solution was stirred for 1 day and then the pyridine was removed under reduced pressure. The resulting solid was redissolved in pyridine $(1.5 \mathrm{~mL})$ and then layered with hexanes $(3 \mathrm{~mL})$. Dark brown needles formed. The solid was collected by filtration on a medium frit, washed with hexanes, and dried under reduced pressure. While this reported synthesis reports the method that yielded the product most consistently, it is important to note that the formation of product was extremely conditions and concentration sensitive although not stoichiometry sensitive. Yield: $0.131 \mathrm{~g}$, $0.081 \mathrm{mmol}, 63 \%$. ${ }^{1} \mathrm{H}$ NMR (360 MHz, pyridine- $d_{5}$ ) $\delta 7.003-6.89$ (br d, 3H), 6.23 (br s, 1H), 5.84 (br, 1H). ${ }^{13} \mathrm{C}$ NMR $(360 \mathrm{MHz}$, pyridine- $\left.d_{5}\right) 159.95,150.77,136.60,129.21,128.14,124.56$, 118.98, 111.08. FTIR (nujol) 3049.33, 2922.30, 2853.02, 1582.33 (vs), 1544.48 (s), 1465.91 (vs), 1439.18, 1377.00, 1298.18 (vs), 1265.63 (vs), 1163.72 (vs), 1149.11, 1071.64, 1030.39, 1018.91, 995.23, 986.20, 862.36, 818.34, 783.64, 746.92 (vs), 702.19 (vs), 608.58, 591.44, 524.12. Elemental analysis calculated for $\mathrm{K}_{5}(\mathrm{py})_{7}\left[\mathrm{Ce}(\mathrm{PhNNPh})_{4}\right] \mathrm{C}_{83} \mathrm{H}_{75} \mathrm{CeK}_{5} \mathrm{~N}_{15}: \mathrm{C}, 61.61 ; \mathrm{H}, 4.67 ; \mathrm{N}$, 12.98. Found: C, 61.25; H, 4.32; N, 12.98\%.

\section{Acknowledgements}

We thank the U.S. Department of Energy, Office of Science, Early Career Research Program (Grant DE-SC0006518) and the University of Pennsylvania for financial support of this work. We also would like to thank the U.S. National Science Foundation for supporting our X-ray diffractometer (CHE-0840438) and for providing us with calculations resources on the Extreme Science and Engineering Discovery Environment (XSEDE) (grant OCI-1053575). We thank Prof. Jay Kikkawa (UPenn) for assistance with the magnetic measurements. We are grateful to Dr. Corwin Booth, Lawrence Berkeley National Laboratory, for his efforts in XAS measurements.

\section{Notes and references}

1 S. Cotton, Lanthanide and Actinide Chemistry, John Wiley and Sons Inc., Hoboken, NJ, 2006.

2 A. W. G. Platt, The Rare Earth Elements: Fundamentals and Applications, John Wiley \& Sons Ltd., Chichester, United Kingdom, 2012.
3 N. G. Connelly and W. E. Geiger, Chem. Rev., 1996, 96, 877910.

4 A. K. Das, Coord. Chem. Rev., 2001, 213, 307-325.

5 T. Imamoto, Y. Koide and S. Hiyama, Chem. Lett., 1990, 19, 1445-1446.

6 T. Kreuzer, E. S. Lox, D. Lindner and J. Leyrer, Catal. Today, 1996, 29, 17-27.

7 T. D. Beeson, A. Mastracchio, J.-B. Hong, K. Ashton and D. W. C. MacMillan, Science, 2007, 316, 582-585.

8 V. Sridharan and J. C. Menendez, Chem. Rev., 2010, 110, 3805-3849.

9 S. W. Gersten, G. J. Samuels and T. J. Meyer, J. Am. Chem. Soc., 1982, 104, 4029-4030.

10 G. A. Molander, Chem. Rev., 1992, 92, 29-68.

11 V. Nair, L. Balagopal, R. Rajan and J. Matthew, Acc. Chem. Res., 2004, 37, 21-30.

12 V. Nair and A. Deepthi, Chem. Rev., 2007, 107, 1862-1891. 13 T.-L. Ho, Synthesis, 1973, 347-354.

14 S. V. More, M. N. V. Sastry and C.-F. Yao, Green Chem., 2006, 8, 91-95.

15 K. Eguchi, T. Setoguchi, T. Inoue and H. Arai, Solid State Ionics, 1992, 52, 165-172.

16 W. Ruttinger and G. C. Dismukes, Chem. Rev., 1997, 97, 124.

17 S. Park, J. M. Vohs and R. J. Gorte, Nature, 2000, 404, 265267.

18 G. A. Deluga, J. R. Salge, L. D. Schmidt and X. E. Verykios, Science, 2004, 303, 993-997.

19 E. P. Murray, T. Tsai and S. A. Barnett, Nature, 1999, 400, 649-651.

20 S. B. Adler, Chem. Rev., 2004, 104, 4791-4844.

21 M. Mogensen, N. M. Sammes and G. A. Tompsett, Solid State Ionics, 2000, 129, 63-94.

22 J. Kaspar, P. Fornasiero and N. Hickey, Catal. Today, 2003, 77, 419-449.

23 J. Kaspar and P. Fornasiero, J. Solid State Chem., 2003, 171, 19-29.

24 R. Burch, Catal. Rev.: Sci. Eng., 2004, 46, 271-333.

25 T. Bunluesin, R. J. Gorte and G. W. Graham, Appl. Catal., B, 1998, 15, 107-114.

$26 \mathrm{Q}$. Fu, H. Saltsburg and M. Flytzani-Stephanopoulos, Science, 2003, 301, 935-938.

27 Y. Li, Q. Fu and M. Flytzani-Stephanopoulos, Appl. Catal., B, 2000, 27, 179-191.

28 J. A. Rodriguez, S. Ma, P. Liu, J. Hrbek, J. Evans and M. Perez, Science, 2007, 318, 1757-1760.

29 L. Vivier and D. Duprez, ChemSusChem, 2010, 3, 654-678.

30 L. Xu and J. Wang, Environ. Sci. Technol., 2012, 46, 1014510153.

31 A. Kawashima, K. Matsubara and K. Honda, Bioresour. Technol., 2008, 99, 3439-3443.

32 M. Dejhosseini, T. Aida, M. Watanabe, S. Takami, D. Hojo, N. Aoki, T. Arita, A. Kishita and T. Adschiri, Energy Fuels, 2013, 27, 4624-4631.

33 N. A. Piro, J. R. Robinson, P. J. Walsh and E. J. Schelter, Coord. Chem. Rev., 2014, 260, 21-36. 
34 J. A. Bogart, A. J. Lewis, M. A. Boreen, H. B. Lee, S. A. Medling, P. J. Carroll, C. H. Booth and E. J. Schelter, Inorg. Chem., 2015, 54, 2830-2837.

35 J. A. Bogart, A. J. Lewis, S. A. Medling, N. A. Piro, P. J. Carroll, C. H. Booth and E. J. Schelter, Inorg. Chem., 2013, 52, 11600-11607.

36 J. Robinson, P. J. Carroll, P. J. Walsh and E. J. Schelter, Angew. Chem., Int. Ed., 2012, 51, 10159-10163.

37 J. R. Robinson, Z. Gordon, C. H. Booth, P. J. Carroll, P. J. Walsh and E. J. Schelter, J. Am. Chem. Soc., 2013, 135, 19016-19024.

38 C. R. Hamilton, R. A. Baglia, A. D. Gordon and M. J. Zdilla, J. Am. Chem. Soc., 2011, 133, 4208-4211.

39 S. K. Kondaveeti, S. Vaddypally, J. D. McCall and M. J. Zdilla, Dalton Trans., 2012, 41, 8093-8097.

40 S. Vaddypally, S. K. Kondaveeti and M. J. Zdilla, Chem. Commun., 2011, 47, 9696-9698.

41 P. B. Hitchcock, A. G. Hulkes, M. F. Lappert and Z. Li, Dalton Trans., 2004, 129-136.

42 W. J. Evans, D. J. Drummond, L. R. Chamberlain, R. J. Doedens, S. G. Bott, H. Zhang and J. L. Atwood, J. Am. Chem. Soc., 1988, 110, 4983-4994.

43 A. A. Trifonov, M. N. Bochkarev, H. Schumann and J. Loebel, Angew. Chem., Int. Ed. Engl., 1991, 30, 1149-1151.

44 K. L. Miller, B. N. Williams, D. Benitez, C. T. Carver, K. R. Ogilby, E. Tkatchouk, W. A. Goddard III and P. L. Diaconescu, J. Am. Chem. Soc., 2010, 132, 342-355.

45 Structural chemistry, ed. R. Allmann, John Wiley \& Sons, New York, 1975.

46 C.-L. Pan, W. Chen and J. Song, Organometallics, 2011, 30, 2252-2260.

47 E. L. Muetterties and C. M. Wright, Q. Rev., Chem. Soc., 1967, 21, 109-194.

48 E. L. Muetterties and L. J. Guggenberger, J. Am. Chem. Soc., 1974, 96, 1748-1756.

49 J. L. Hoard and J. V. Silverton, Inorg. Chem., 1963, 2, 235242.

50 L. Yang, D. R. Powell and R. P. Houser, Dalton Trans., 2007, 955-964.

51 T. S. Calderwood, C. L. Johlman, J. L. Roberts Jr., C. L. Wilkins and D. T. Sawyer, J. Am. Chem. Soc., 1984, 106, 4683-4687.

52 M. J. Zdilla, A. K. Verma and S. C. Lee, Inorg. Chem., 2008, 47, 11382-11390.

53 M. J. Zdilla, A. K. Verma and S. C. Lee, Inorg. Chem., 2011, 50, 1551-1562.

54 D. S. J. Arney and C. J. Burns, J. Am. Chem. Soc., 1995, 117, 9448-9460.

55 W. J. Evans, G. Kociok-Kohn, V. S. Leong and J. W. Ziller, Inorg. Chem., 1992, 31, 3592-3600.

56 B. Gemund, H. Noth, H. Sachdev and M. Schmidt, Chem. Ber., 1996, 129, 1335-1344.

57 Y. Ohki, Y. Takikawa, T. Hatanaka and K. Tatsumi, Organometallics, 2006, 25, 3111-3113.

58 F. Alonso, G. Radivoy and M. Yus, Tetrahedron, 2000, 56, 8673-8678.
59 J. M. Hoover, A. DiPasquale, J. M. Mayer and F. E. Michael, Organometallics, 2007, 26, 3297-3305.

60 Y. Nakajima and H. Suzuki, Organometallics, 2003, 22, 959969.

61 A. F. Heyduk, R. A. Zarkesh and A. I. Nguyen, Inorg. Chem., 2011, 50, 9849-9863.

62 R. A. Zarkesh and A. F. Heyduk, Organometallics, 2011, 30, 4890-4898.

63 D. Werner, G. B. Deacon, P. C. Junk and R. Anwander, Chem.-Eur. J., 2014, 20, 4426-4438.

64 A. Sen, H. A. Stecher and A. L. Rheingold, Inorg. Chem., 1992, 31, 473-479.

65 J. R. Robinson, C. H. Booth, P. J. Carroll, P. J. Walsh and E. J. Schelter, Chem.-Eur. J., 2013, 19, 5996-6004.

66 D. H. Kim, U. S. Shin and C. E. Song, J. Mol. Catal. A: Chem., 2007, 271, 70-74.

67 S. Fukuzumi and K. Ohkubu, Chem.-Eur. J., 2000, 6, 45324535.

68 S. Fukuzumi, N. Satoh, T. Okamoto, K. Yasui, T. Suenobu, Y. Seko, M. Fujitsuka and O. Ito, J. Am. Chem. Soc., 2001, 123, 7756-7766.

69 S. Fukuzumi, Y. Fujii and T. Suenobu, J. Am. Chem. Soc., 2001, 123, 10191-10199.

70 S. Fukuzumi, J. Synth. Org. Chem., Jpn., 2003, 61, 1046-1055.

71 S. Fukuzumi, Org. Biomol. Chem., 2003, 1, 609-620.

72 K. Ohkubo, T. Suenobu, H. Imahori, A. Orita, J. Otera and S. Fukuzumi, Chem. Lett., 2001, 978-979.

73 K. Ohkubo, S. C. Menon, A. Orita, J. Otera and S. Fukuzumi, J. Org. Chem., 2003, 68, 4720-4726.

74 J. Park, Y. Morimoto, Y.-M. Lee, W. Nam and S. Fukuzumi, Inorg. Chem., 2014, 53, 3618-3628.

75 D. F. Evans, J. Chem. Soc., 1959, 2003-2005.

76 E. M. Schubert, J. Chem. Educ., 1992, 69, 62.

77 M. D. Walter, R. Fandos and R. A. Andersen, New J. Chem., 2006, 30, 1065-1070.

78 A. Panagiotopoulos, T. F. Zafiropoulos, S. P. Perlepes, E. Bakalbassis, I. Masson-Ramade, O. Kahn, A. Terzis and C. P. Raptopoulou, Inorg. Chem., 1995, 34, 4918-4920.

79 C. Benelli and D. Gatteschi, Chem. Rev., 2002, 102, 23692388.

80 H. An, H. Zhang, Z. Chen, Y. Li, X. Liu and H. Chen, Dalton Trans., 2012, 41, 8390-8400.

81 C. A. Smith, E. W. Ainscough, H. M. Baker, A. M. Brodie and E. N. Baker, J. Am. Chem. Soc., 1994, 116, 7889-7890.

82 M. P. Andersson and P. Uvdal, J. Phys. Chem. A, 2005, 109, 2937-2941.

83 K. K. Irikura, R. D. Johnson III and R. N. Kacker, J. Phys. Chem. A, 2005, 109, 8430-8437.

84 H.-G. Cho and L. Andrews, Organometallics, 2012, 31, 535544.

85 X. Wang, L. Andrews, B. Vlaisavljevich and L. Gagliardi, Inorg. Chem., 2011, 50, 3826-3831.

86 X. Wang, H.-G. Cho, L. Andrews, M. Chen, D. A. Dixon, H.-S. Hu and J. Li, J. Phys. Chem. A, 2011, 115, 1913-1921.

87 D. D. Weis and G. E. Ewing, Anal. Chem., 1998, 70, 31753183. 
88 A. R. Crozier, A. M. Bienfait, C. Maichle-Mossmer, K. W. Tornroos and R. Anwander, Chem. Commun., 2013, 49, 87-89.

89 U. J. Williams, D. Schneider, W. L. Dorfner, C. MaichleMossmer, P. J. Carroll, R. Anwander and E. J. Schelter, Dalton Trans., 2014, 43, 16197-16206.

90 S. Vaddypally, S. K. Kondaveeti, J. H. Roudebush, R. J. Cava and M. J. Zdilla, Chem. Commun., 2014, 50, 1061-1063.

91 D. Quane, J. Chem. Educ., 1970, 47, 396-398.

92 D. F. C. Morris, Acta Crystallogr., 1956, 9, 197-198.

93 D. C. Bradley, J. S. Ghotra and F. A. Hart, J. Chem. Soc., Dalton Trans., 1973, 1021-1023.

94 G. A. Bain and J. F. Berry, J. Chem. Educ., 2008, 85, 532-536. 95 SAINT, Bruker AXS Inc., Madison, Wisconsin, USA, 2009. 96 SHELXTL, Bruker ASX Inc., Madison, Wisconsin, USA, 2009.

97 G. M. Sheldrick, TWINABS, University of Gottingen, Gottingen, Germany, 2008.

98 G. M. Sheldrick, $S A D A B S$, University of Gottingen, Gottingen, Germany, 2007.

99 G. M. Sheldrick, Acta Crystallogr., Sect. A: Found. Crystallogr., 2008, 64, 112-122.

100 M. J. Frisch, G. W. Trucks, H. B. Schlegel, G. E. Scuseria, M. A. Robb, J. R. Cheeseman, G. Scalmani, V. Barone,
B. Mennucci, G. A. Petersson, H. Nakatsuji, M. Caricato, X. Li, H. P. Hratchian, A. F. Izmaylov, J. Bloino, G. Zheng, J. L. Sonnenberg, M. Hada, M. Ehara, K. Toyota, R. Fukuda, J. Hasegawa, M. Ishida, T. Nakajima, Y. Honda, O. Kitao, H. Nakai, T. Vreven, J. A. Montgomery Jr., J. E. Peralta, F. Ogliaro, M. Bearpark, J. J. Heyd, E. Brothers, K. N. Kudin, V. N. Staroverov, R. Kobayashi, J. Normand, K. Raghavachari, A. Rendell, J. C. Burant, S. S. Iyengar, J. Tomasi, M. Cossi, N. Rega, N. J. Millam, M. Klene, J. E. Knox, J. B. Cross, V. Bakken, C. Adamo, J. Jaramillo, R. Gomperts, R. E. Stratmann, O. Yazyev, A. J. Austin, R. Cammi, C. Pomelli, J. W. Ochterski, R. L. Martin, K. Morokuma, V. G. Zakrzewski, V. Voth, J. Cioslowski and D. J. Fox, Gaussian 09, Revision D.01, Gaussian, Inc., Wallingford, CT, 2009.

101 Institute for Theoretical Chemistry, University of Cologne, http://www.tc.uni-koeln.de/PP/clickpse.en.html.

102 X. Cao and M. Dolg, J. Mol. Struct.: THEOCHEM, 2002, 581, 139-147.

103 M. Dolg, H. Stoll and H. Preuss, J. Chem. Phys., 1989, 90, 1730-1734.

104 Chemcraft, http://www.chemcraftprog.com. 